\title{
AUTORYTETY W DEBACIE UNIJNEJ
}

\begin{abstract}
Ż yjemy w coraz bardziej skomplikowanym świecie. Choć w rzeczywistości się on nie zmienia, to nasza nieustannie wzrastająca wiedza na jego temat powoduje, że paradoksalnie jesteśmy coraz bardziej zagubieni. Rozwój nauki doprowadził do tego, że raczej niemożliwe jest istnienie współczesnych Arystotelesów, którzy zajmowaliby się jednocześnie filozofia, fizyka, medycyna, politologia, psychologią itp. W znacznie większym stopniu niż kiedyś musimy polegać na wąskich specjalistach zgłębiających tylko wybrane wycinki rzeczywistości. O tym, jak bardzo jest to niebezpieczne, świadczyć może eksperyment Stanleya Miligrama, w którym badane osoby były w stanie, pod wpływem autorytetu, zadawać śmiertelny ból innym ludziom¹. Warto również dodać, że taka postawa nie jest charakterystyczna tylko dla Amerykanów, ponieważ podobne wyniki uzyskano, badając Holendrów, Niemców, Hiszpanów, Włochów, Australijczyków i Jordańczyków².

Równie niepokojące moga być wyniki innych eksperymentów. Jeden $z$ badaczy zadzwonił do 22 pielęgniarek z różnych szpitali podszywając się pod doktora i kazal podawać pacjentom niewłaściwy lek oraz nieodpowiednią jego dawkę. Dwadzieścia jeden $\mathrm{z}$ nich było gotowe wykonać polecenie, chociaż zdawały sobie sprawę, że wydawanie poleceń przez telefon było naruszeniem zasad obowiązujących w szpitalu. Biorąc pod uwagę, że 12\% zleceń na podanie leków jest błędnych, jest czego się bać3.

$\mathrm{Na}$ uwagę zasługuje również fakt nie tylko bezkrytycznego podporządkowania się autorytetom, ale również niedoceniania nowych
\end{abstract}

${ }^{1}$ R. Cialdini, Wywieranie wplywu na ludzi, Gdańsk 1996, s. 193.

2 Tamże, s. 196.

3 Tamże, s. 203. 
pomysłów ludzi, którzy jeszcze nie zdążyli wyrobić sobie dobrej opinii. Dwóch psychologów: Douglas Peters i Stephen Ceci przepisało na maszynie 12 artykułów opublikowanych w periodykach naukowych. Zamienili jednak znane nazwiska $i$ instytucje, $z$ których wywodzili się autorzy, na nazwiska nieznane oraz nieznane instytucje. Po okresie od 18 do 32 miesięcy zwrócili się do tych samych periodyków z prośbą o opublikowanie artykułów „nieznanych” autorów. Trzy z nich zostały wykryte jako plagiaty, natomiast w przypadku ośmiu stwierdzono, że nie spełniają odpowiednich wymogów, chociaż wcześniej je spełniały ${ }^{4}$.

Warto podkreślić, że osoby pracujące w specjalistycznych czasopismach to raczej ludzie znający się na danej dyscyplinie. Również pielęgniarki powinny mieć elementarną wiedzę medyczną, a ludzie z eksperymentu Miligrama winni wiedzieć, że rażenie prądem innych może być niebezpieczne zarówno dla zdrowia jak i życia. Można więc zadać pytanie: skąd biora się takie zachowania? Czy są one w pełni świadome? Należy dodać, że wśród 33 pielęgniarek, które zapytano, jak zachowałyby się w opisanej powyżej sytuacji, tylko dwie stwierdziły, ze podałyby pacjentowi zły lek ${ }^{5}$.

Podobne zachowania jak u ludzi można zaobserwować u małp. Gdy jednemu $\mathrm{z}$ tych zwierząt (o niskiej pozycji w hierarchii) dano kij ułatwiający sięgnięcie po niedostępne jedzenie, nikt go nie naśladował. Natomiast, gdy podano kij osobnikowi dominującemu, inne małpy również zaczęły $z$ niego korzystać ${ }^{6}$ Być może więc nasze podporządkowanie autorytetom wynika nie tylko $\mathrm{z}$ uwarunkowań społecznych w jakich żyjemy, ale również z naszych genów.

W Polsce zdecydowanie za najwybitniejszy autorytet uznawany jest obecny papież, Jan Paweł II. Według badań CBOS-u z marca 1996 r., dla 94\% Polaków papież jest autorytetem intelektualnym, dla 92\% religijnym, dla 91\% moralnym, a dla $89 \%$ narodowym. Ponadto $60 \%$ badanych uważa, że nie można krytykować papieża, 39\% że można, a 1\% nie ma zdania. Natomiast $45 \%$ Polaków stwierdziło, że papież bardzo dobrze rozumie obecną sytuację w Polsce, a 34\%, że dobrze ${ }^{7}$. Z badań OBOP-u z listopada 1994 r. wynika natomiast, że tylko 21\% Polaków uważa papieża za największy autorytet, co jednak nie przeszkodziło mu zająć pierwszego miejsca w rankingu. Daleko za nim uplasowali się: Waldemar Pawlak (5\%), Aleksander Kwaśniewski i Jacek Kuroń (4\%), Wojciech Jaruzelski, Lech Wałęsa, Tadeusz Zieliński (po 3\%) i Ewa

${ }^{4}$ Tamże, s. 204.

5 Tamże.

${ }^{6}$ Tamże, s. 200.

${ }^{7}$ R. Dyoniziak, Sondaże a manipulowanie spoteczeństwem, Kraków 1997, s. 56-57. 
Lętowska (2\%). Na uwagę zasługuje fakt, że aż $24 \%$ badanych odpowiedziało, że nie ma żadnego autorytetu, natomiast $12 \%$ ankietowanych zaznaczyło odpowiedź „trudno powiedzieć”. ${ }^{\text {. Oznacza }}$ to, że choć papież rzeczywiście jest uznawany przez Polaków za największy autorytet, to jednak największa liczba badanych wskazała, iż nie ma żadnego autorytetu. Ciekawa jest również duża różnica między badaniami OBOP-u i CBOS-u, choć trzeba wziąć pod uwagę fakt, że pytania były inaczej sformułowane oraz, że badania były przeprowadzone w odstępie dwóch lat.

Mimo, iż przytoczone badania zostały przeprowadzone już jakiś czas temu, można przypuszczać, że dzisiaj ich wyniki niewiele by się różniły. $\mathrm{Na}$ pewno zmianie uległyby autorytety polityczne, ponieważ zależą one od wielu różnych czynników. Jednak silna pozycja papieża oraz duża liczba osób nieposiadająca żadnych autorytetów raczej powinny się utrzymać. Nie znaczy to jednak, że część Polaków ulega tylko autorytetowi papieża, a druga część nie ulega żadnym autorytetom. Badania tego typu można by porównać do badań przeprowadzonych na pielęgniarkach, które stwierdziły, że nie wykonałyby błędnego polecenia lekarza, choć w rzeczywistości postapiły inaczej. Ponadto badania przeprowadzone przez CBOS i OBOP dotyczyły w dużej mierze autorytetów natury moralnej, a pod tym względem, każdy może kierować się swoim własnym kodeksem. Inaczej jednak jest w sytuacjach skomplikowanych, gdy nie potrafimy sami zająć stanowiska w jakiejś kwestii. Wtedy często szukamy ludzi lepiej zorientowanych, których w tym momencie możemy uważać za autorytet, choć nigdy ich nazwiska nie wpisalibyśmy w ankiecie. Można powiedzieć, że jednym $z$ takich skomplikowanych problemów jest integracja Polski z UE.

\section{Autorytety ekspertów}

Eksperci to ludzie znający się na danym temacie. Stąd też posługiwanie się ich autorytetem nie musi być koniecznie manipulacją, choć jak to zostało powyżej opisane, czasami może być niebezpieczne. Nigdy też nie można mieć całkowitej pewności czy powoływanie się na opinie eksperta jest uczciwe, czy też ktoś się posługuje przeinaczonym lub wyrwanym $z$ kontekstu cytatem. Problemem może być również fakt, iż na ten sam temat różni specjaliści moga mieć całkiem odmienne przekonania. Jednym z przykładów takiego stanu rzeczy była m.in. debata o Unii Europejskiej.

\footnotetext{
${ }^{8}$ Http:www.tns-global.pl.
} 
W dyskursie unijnym można było usłyszeć więc, zarówno ze strony „euroentuzjastów” jak i „eurosceptyków”, wiele cytatów, przy których często podkreślano, że słowa pochodzą bądź to od profesora, bądź to od urzędnika unijnego, a czasami używano nawet takich enigmatycznych sformułowań jak np. „Są intelektualiści, którzy twierdzą, że UE to nowy Związek Sowiecki”, lub „Niech pani poczyta opracowania odpowiednich gremiów opiniotwórczych" ${ }^{\text {. }}$. Takie słowa przeważnie padały z ust „eurosceptyków”. Trudno powiedzieć czy wynikało to z faktu, iż nie wiedzieli oni skąd posiadają dane informacje, czy też może ze strachu przed ujawnieniem źródła. Jest duże prawdopodobieństwo, że niektórzy „euroentuzjaści” dowiadując się, iż dane pochodzą z mediów lub publikacji typowo „eurosceptycznych” zareagowaliby śmiechem. Dlatego też przeciwnicy UE często stosowali zabieg polegający na powoływaniu się na autorytety szanowane przez przeciwnika, czyli ludzi popierających wejście do UE, ale dostrzegających pewne problemy, które nie zawsze były dostrzegane przez niektórych „euroentuzjastów”. Jak powiedział w jednym ze swoich przemówień sejmowych Bogdan Pęk (LPR): „Ponieważ mój głos, człowieka związanego z formacją przeciwna wejściu Polski do UE, (...) nie mógłby być w pełni wiarygodny, posłużę się cytatami takich dżentelmenów, którzy przez wiele lat odpowiadali, prowadząc Polskę do integracji europejskiej, a w tym przypadku mam na myśli Jacka Saryusza-Wolskiego, który zatytułował pewien artykuł w niemieckiej prasie „Ekonomiczny apartheid"". Wielkie zdziwienie pojawiło się na twarzach zwolenników UE, gdy przedstawiciel młodzieżówki UPR - Stanisław Wojtera, odpowiedział im na pytanie, że niewygodne dla nich informacje pochodzą z „Rzeczpospolitej”. Towarzyszyły temu owacje ze strony „eurosceptyków”"12. Ten sam polityk powoływał się również na prognozy IBnGR oraz na dra Gwiazdowskiego z CAS i podkreślał, że choć są to zwolennicy UE, uważaja oni, iż przez pierwsze trzy lata będziemy płatnikami netto ${ }^{13}$. Odwoływał się on również do badań naukowców holenderskich na temat funduszy strukturalnych, charakterystycznie podkreślając słowa świadczące o ich autorytecie: „Ostatnio eksperci, profesorowie jednego z uniwersytetów holenderskich, czyli w Holandii, która jest członkiem UE, stwierdzili po dokonaniu analiz, że w 13 krajach na 15, fundusze

${ }^{9}$ E. J. Moskal, Oświadczenie Kongresu Polonii Amerykańskiej w sprawie praystapienia Polski do Unii Europejskiej, „Niedziela”, 2003, nr 6.

10 Tygodnik polityczny Jedynki, TVP1, 05.06.2003.

${ }^{11}$ Http:www.sejm.gov.pl/oide.

12 Tygodnik polityczny Jedynki, TVP1, 05.06.2003.

13 Tamże. 
strukturalne hamują rozwój gospodarczy, ponieważ przez współfinansowanie wzrasta obciążenie podatkowe, po drugie fundusze strukturalne nie ida za głosem rynku" ${ }^{\prime 14}$.

Jednak najbardziej charakterystycznym autorytetem, na którego powoływali się „eurosceptycy”, był były urzędnik unijny, Carl Beddermann. Przeciwnicy UE bardzo często wykorzystywali jego słowa, by oskarżyć „euroentuzjastów” o zdradę: „Jest taki były urzędnik UE, Niemiec pan Karol Beddermann, który został wyrzucony na bruk za to, że wcześniej pracując w Polsce i oglądając rzeczywistość unijną i przystosowania, powiedział Polakom: „To się wam nie opłaca”. Opowiadał mi on, że jako niemieckie dziecko w niemieckiej szkole uczony był, że rozbiory Polski dokonane zostały z inicjatywy polskich przywódców i on nie mógł w to uwierzyć. Dopiero jak teraz przyjechał to uwierzył" ". Równie często przywoływana była unijna komisarz do spraw budżetu - Michaele Schreyer: „Cieszy się pani komisarz do spraw budżetu UE, która mówi: > Rozszerzenie okazało się o wiele tańsze niż początkowo przypuszczano, trudno o korzystniejszą cenę<"16. Padały również sformułowania bardziej ogólnikowe jak: „Byli eksperci unijni mówią, że zlikwidowane będzie około 85\% gospodarstw rolnych"17. Podobnie ogólnikowo pisał ks. Lucjan Balter w „Naszym Dzienniku”: „Urzędnicy unijni obliczyli, że gdyby nie to otwarcie, bezrobocie w krajach unijnych wzrosłoby w ostatnim dziesięcioleciu o 5\%, a w Polsce zmalało o 15\%"18. Natomiast Janusz Maksymiuk z Samoobrony powołał się w programie „Forum” na „Trybunę”, w której podobno napisano, że komisarz ds. poszerzenia UE Günter Verheugen powiedział, że: „Gdyby miał głosować jako Polak za warunkami, to nigdy by za takimi warunkami nie głosował, bo warunki ekonomiczne sa złe" ${ }^{\text {"19. }}$. Niektórzy „euroentuzjaści”, jak np.: Donald Tusk z PO, nie bardzo wiedzieli, jak odpowiedzieć „eurosceptykom” powołującym się na autorytety unijnych komisarzy. Gdy podczas spotkania z mieszkańcami Torunia jeden z uczestników zapytał się go, co sądzi o Carlu Beddermanie, marszałek sejmu bronił się, stosując argumentum ad hominem (argument odwołujący się do racji przeciwnika ${ }^{20}$ i wykorzystując antyniemieckie fobie LPR, odpowiedział: „Jeśli LPR za swojego doradcę bierze sobie Niemca, to ja

\footnotetext{
14 Tamże.

${ }^{15}$ Http:www.sejm.gov.pl/oide.

16 Tamże.

17 Tamże.

${ }^{18}$ Ks. L. Balter, Unia kosztem Polski, „Nasz Dziennik”, 02.01.2003.

${ }^{19}$ Forum, TVP1, 27.05.2003.

${ }^{20}$ M. Korolko, Retoryka i erystyka dla prawników, Warszawa 2001, s. 102.
} 
im gratuluję"21. Ad hominem stosowali również czasem „eurosceptycy” przypominając „euroentuzjastom”, co mówili kiedyś. Trzeba przyznać, że często, jak np.: w przypadku Jerzego Roberta Nowaka, ich wątpliwości były uzasadnione: „Premier Oleksy powiedział w wywiadzie, że jeśli będziemy musieli płacić pełną składkę do Unii, to siadamy, sytuacja jest nie do przyjęcia, bo będziemy płatnikiem netto"22. Jak się okazało, jednak trzeba zapłacić pełną składkę. Przedstawiciel młodzieżówki Samoobrony powoływał się również na raport NIK, który nie był zbyt „euroentuzjastyczny”: „Chciałbym żebyście się odnieśli do raportu NIK, z którego jasno wynika, że zadłużone samorządy nie będą mogły skorzystać z funduszy"23.

$\mathrm{Na}$ autorytety unijnych komisarzy oraz innych europejskich polityków powoływali się również „euroentuzjaści”. Leszek Miller w swoim wystapieniu sejmowym raczej nie bez powodu nawiązywał do Willy Brandta - pierwszego niemieckiego kanclerza, który uznał polskie granice: „Parafrazując słowa Willy Brandta, można powiedzieć, że jako Europejczycy przeszliśmy ogromna drogę: od ostrego podziału i bycia przeciwko sobie - poprzez współistnienie i bycie obok siebie - do bycia razem”24. „Rzeczpospolita” natomiast opublikowała 6 czerwca 2003 roku wypowiedzi takich polityków jak: Mary McAlesee - prezydent Irlandii, Günter Verheugen - komisarz ds. poszerzenia UE, Pat Cox przewodniczący PE, Javier Solana - przedstawiciel UE ds. polityki zagranicznej i bezpieczeństwa, Göran Persson - premier Szwecji, Giafranco Fini - wicepremier Włoch, Kostas Simitis - premier Grecji oraz Joschka Fischer - niemiecki minister spraw zagranicznych. Wszystkie z tych wypowiedzi wyraźnie zachęcały do głosowania na „tak"25. Warto zauważyć, że zostały one opublikowane w dzień ciszy przedreferandalnej. Jeśli chodzi o antyunijnych polityków europejskich to ulubionym autorytetem dla „eurosceptyków” była Margaret Thatcher. O ile nie ma w tym nic szczególnie dziwnego, gdy powoływali się na nią przedstawiciele UPR, o tyle w przypadku prawicy katolicko-narodowej może się to wydawać trochę komiczne, ponieważ była premier Wielkiej Brytanii opowiadała się za całkowicie wolnym rynkiem. Nie przeszkodziło to jednak „Naszemu Dziennikowi” w pisaniu: „Wielu

\footnotetext{
${ }^{21}$ Nagranie własne.

22 Tygodnik polityczny Jedynki, TVP1, 05.06.2003.

23 Tamże.

${ }^{24}$ Http: www.sejm.gov.pl/oide.

${ }^{25}$ Europa czeka na Polske, „Rzeczpospolita”, 06.06.2003.
} 
brytyjskich polityków, na czele z była premier Margaret Thatcher już od dawna postuluje wyjście Wielkiej Brytanii ze struktur UE”26.

Obie strony debaty unijnej powoływały się oczywiście na autorytety naukowe. Między innymi Mirosław Głogowski w „Przeglądzie” cytował wypowiedzi wielu przedstawicieli świata nauki, za każdym razem przed nazwiskiem pisząc „prof.” Cytował m.in. Jana Winieckiego: „A niech przyjdą i nas wykupia. Ale o wiele bardziej obawiałbym się, gdyby nie chcieli" ${ }^{\text {27}}$; Leszka Ziemkowskiego: „to, co złego miało się stać (...) w większości się stało”28; Grzegorza Gorzelaka, który: „wyliczył, że nieprzystapienie Polski do Unii tylko w latach 2004 - 2006 wygeneruje bilansowo stratę dla Polski 7 mld euro" 29 oraz Luca Bernarda: „większość zachodnich inwestorów nie lubi ryzyka, więc dopiero po wejściu do unii nastąpi to, co zdarzyło się w Hiszpanii w drugiej połowie lat 80. To była prawdziwa eksplozja, dzięki której doszło do szybkiej modernizacji gospodarki hiszpańskiej”30. W „Trybunie” natomiast napisano: „Zdaniem Rafała Antczaka z Centrum Analiz SpołecznoEkonomicznych, [jeżeli nie wejdziemy do UE] może się zrealizować czarny scenariusz, czyli osłabienie naszej waluty nawet o 30-40\%"31. Bardzo często powoływano się również na tzw. „niezależne” raporty: „Niezależni ekonomiści z największych ośrodków badawczych i ekonomicznych przygotowali na zlecenie KIE raport: „Bilans korzyści i kosztów integracji z UE". Przedstawia on dwa scenariusze: Polskę w UE i Polskę poza wspólnota. W pierwszym wypadku PKB wzrosnąć ma po 10 latach z dzisiejszych $40 \%$ średniej unijnej do 55\% i wynieść ponad $5 \%$ rocznie. Inflacja ma przekroczyć 4\%, bezrobocie od 2007r. ma spadać znacznie szybciej niż w wariancie pozaunijnym"32. Jednym z tych „niezależnych” ekspertów był doradca prezydenta Aleksandra Kwaśniewskiego - Witold Orłowski, człowiek o poglądach zdecydowanie prounijnych. Zdarzało się też, że „euroentuzjaści” wykorzystywali autorytet, by zdyskredytować przeciwnika: „Fanatyk nie słyszy argumentów - mówi socjolog prof. Paweł Śpiewak" ${ }^{\text {33. }}$.

„Eurosceptycy” natomiast oprócz wspomnianych już IBnGR i CAS powoływali się również na prof. Bojarskiego. Jak mówił z trybuny poseł

\footnotetext{
${ }^{26}$ W. Moszkowski, Klauzula myjscia klauzula niewoli”, „Nasz Dziennik”, 14.04.2003.

${ }^{27}$ M. Głogowski, Co będrie jeśli odrzucimy wejście do Unii, „Przegląd”, 2003, nr 21.

28 Tamże.

${ }^{29}$ Tamże.

30 Tamże.

${ }^{31}$ B. Wawro, Droga bezpobocza, ,Trybuna”, 15.05.2003.

32 M. Przeczek, Tylko jeden maly krok, „Trybuna”, 23.04.2003.

${ }^{3}$ M. Ostrowski, E. Świątkowska, Nas do Unii nie ragonia, „Polityka”, 2003, nr 11.
} 
RKN Antoni Stryjewski: „W bilansie prof. Bojarskiego wyszła ogromna strata ok. 600 mld zł”" ${ }^{\prime 34}$. Często mówiono również o wynikach badań przeprowadzonych przez Wyższą Szkołę Zarządzania i Administracji w Zamościu na podstawie programu zleconego przez Centrum Europejskie Natolin w Warszawie, z których wynika, że: „70\% małych i średnich przedsiębiorstw i 40\% gospodarstw rolnych może zbankrutować, a to spowoduje lawinę zwiększenia bezrobocia. To dotyczy również innych regionów rolniczych, a do badania zostały wybrane najlepsze regiony rolne" ${ }^{35}$. Nierzadko powoływano się również na ekspertyzę Waldemara Gontarskiego: „Możliwość wprowadzenia zmian stwarza artykuł 23 traktatu w części poświęconej rolnictwu. Modyfikacja mogłaby zostać dokonana przed ewentualnym przystapieniem Polski do UE. Możliwość taka potwierdza ekspertyza prawna przeprowadzona przez dyrektora Centrum Ekspertyz Prawnych przy Europejskiej Szkole Prawa i Administracji, Waldemara Gontarskiego" "36. „Nasz Dziennik” w trosce o suwerenność Polski powoływał się na Friedricha Romiga: „Profesor Friedrich Romig na spotkaniach (...) mówił z doświadczenia obywatela kraju należącego od 5 lat do UE, że akcesja jest utratą suwerenności. Jednym z przykładów podanych przez gościa z Austrii jest fakt, że około $80 \%$ przepisów prawnych jest ustanowionych przez UE, a nie przez państwo członkowskie" ${ }^{37}$. Jerzy Robert Nowak, który w środowisku „,eurosceptycznym” również uchodzi za autorytet, w swojej antyunijnej publicystyce powoływał się na słowa m.in: Miltona Friedmana, Johna Kennetha Galbraitha oraz Carla Poppera, np.: „Profesor Carl Popper słynny politolog brytyjski (...) już w 1993 roku ostrzegł Polaków na łamach „Wprost”: „Na rozkaz brukselskich biurokratów dusicie się własnymi rękami. W momencie, gdy już dopłyniecie do waszej wymarzonej Brukseli, wasze wyroby będą całkowicie niekonkurencyjne. Będziecie załatwieni" ${ }^{38}$.

Programem telewizyjnym, w którym dużą rolę odgrywały autorytety, był „Tygodnik polityczny Jedynki”. Jego formuła polegała bowiem na tym, że po jednej stronie siedzieli zwolennicy UE, po drugiej stronie przeciwnicy UE, zaś pośrodku eksperci. Problem polega jednak na tym, że eksperci często nie ukrywali swojego „euroentuzjazmu”. Jednym z nich był dr Jerzy Andrzej Wojciechowski - „ekspert prawa

\footnotetext{
${ }^{34}$ Http:www.sejm.gov.pl/oide.

35 Tamże.

${ }^{36}$ Cyt. za: Http:euro.pap.com.pl/cgi-bin/europap.pl.

${ }^{37}$ K. Cegielska, Dlaczego chcecie utracić suwerenność, „Nasz Dziennik”, 22-23.03.2003.

38 J.R. Nowak, Świat unijnych iluzji, „Nasz dziennik”, 11.03.2003.
} 
europejskiego" 39 . Kontrowersje może budzić fakt, iż ten sam człowiek, który w programie publicystycznym występował jako bezstronny fachowiec, równocześnie brał udział w prounijnych reklamach rządowych. Niestety ograniczenia czasowe programu (a może nie tylko czasowe?) doprowadzały czasem do komicznych sytuacji, gdy ze zdaniem Jerzego Andrzeja Wojciechowskiego nie można było polemizować. Kiedy przedstawiciel PP, Jan Łopuszański, chciał zadać pytanie ekspertowi, otrzymywal od redaktora prowadzacego program następujące odpowiedzi: „Panie pośle, nie ma już dyskusji w tej sprawie.

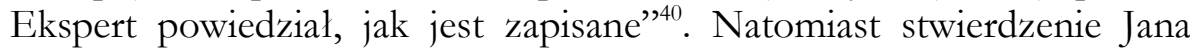
Łopuszańskiego, że „to są nieprawdziwe informacje”"41, zostało skomentowane: „Nie, to nie sa nieprawdziwe informacje, ponieważ ekspert powiedzial, jak jest zapisane w traktacie" ${ }^{42}$. Padały również zdania typu: „Trudno mi dyskutować, jeżeli ekspert mówi coś, a pan się z tym nie zgadza.” oraz „Ekspert powiedział to, co jest zapisane, proszę nie dyskutować... bo to nie ma sensu"43. W końcu jednak udało się posłowi Łopuszańskiemu zadać pytanie. Oczywiście zrozumiałe jest, że żadnego programu nie można przeciagać w nieskończoność, jednak obsadzenie w roli eksperta człowieka kojarzonego z kampanią prounijna oraz zakaz polemiki z nim pozwala domniemywać, że ograniczenia czasowe nie były jedyną przeszkoda. Prawdopodobnie więcej czasu zaoszczędziłby redaktor programu, gdyby pozwolił od razu zadać pytanie, nie wdając się w dyskusję na temat autorytetu eksperta.

Nie brakowało również w debacie unijnej chwytu erystycznego, który polega na ukazywaniu siebie samego jako autorytetu. Roman Giertych (LPR) stwierdził na przykład, że jest on jedną z nielicznych osób w kraju, która przeczytała cały traktat akcesyjny (poza nim jest podobno nie więcej niż dziesięciu takich ludzi ${ }^{44}$. $\mathrm{Na}$ autorytet próbowała się również wykreować Danuta Hojarska z Samoobrony, mówiąc: „Ja jestem członkiem komisji rolnictwa, ustawę o ustroju rolnym znam na pamięć" ${ }^{5}$ oraz „Chwileczkę jestem członkiem sejmowej komisji rolnictwa, wiele rzeczy wiem"46. Podobnie zachowywał się przedstawiciel Młodych Demokratów, Michał Matejka: „Otóż ja jestem studentem trzeciego roku

39 Tygodnik polityczny Jedynki, TVP1, 23.05.2003.

40 Tamże.

${ }^{41}$ Tamże.

${ }^{42}$ Tamże.

43 Tamże.

${ }^{44}$ P. Najsztub, R. Giertych, Tako rzecze Giertych, „Przekrój”, 18.05.2003.

45 Tygodnik polityczny Jedynki, TVP1, 29.05.2003.

46 Tamże. 
prawa i pozwolę sobie udzielić odpowiedzi na to jakże absorbujące pytanie”47. Niektórzy „eurosceptycy” powoływali się natomiast nie na swój autorytet, lecz na autorytet swoich partyjnych kolegów. Zrobiła tak posłanka LPR, Halina Murias: „Dlaczego nie mówicie społeczeństwu o pochodzeniu UE, o jej masońskich korzeniach, o czym nie tak dawno mówił pan prof. Maciej Giertych, poseł LPR" ${ }^{\text {"48 }}$.

Rozbieżność zdań wielu autorytetów może świadczyć o tym, jak trudne do przewidzenia są skutki wejścia Polski do UE. Jednak nie tylko dyskurs unijny, ale dyskurs polityczny w całości charakteryzuje się tym, że większość podejmowanych tematów jest bardzo kontrowersyjna. Politycy często posługują się więc autorytetami ze świata nauki. Nie należy jednak zapominać, że w takich sprawach jak polityka czy gospodarka nawet najlepszym naukowcom trudno podjąć obiektywna decyzję, całkowicie niezależną od własnych poglądów. Trudności te zresztą moga dotyczyć nawet przedstawicieli nauk przyrodniczych, czego przykładem może być debata na temat biopaliw, podczas której przytaczali oni bardzo zróżnicowane ekspertyzy. O tym, jak wielu naukowców biorących udział w debacie unijnej było zaangażowanych po jakiejś konkretnej stronie, może świadczyć wspomniany powyżej przypadek dra Jerzego Andrzeja Wojciechowskiego, będącego w zależności od sytuacji niezależnym ekspertem lub agitatorem. Natomiast ukazywanie siebie lub swoich partyjnych kolegów jako autorytetów w większości dotyczyło „eurosceptyków”. Przyczyną tego mógł być fakt, iż często byli oni przedstawiani jako ludzie słabo wykształceni, choć czasami rzeczywiście tak było.

\section{Autorytety ludzi popularnych}

Jedną z cech charakterystycznych dla debaty o integracji europejskiej byl fakt wykorzystywania w niej ludzi popularnych. Związane to było z tym, iż nie była to zwykła debata, ale także kampania referendalna, mająca zachęcić społeczeństwo do głosowania w odpowiedni sposób. Przypominała więc pod pewnymi względami kampanie wyborcze, a te $z$ kolei często przypominaja kampanie reklamowe. Natomiast w tego typu kampaniach nierzadko wykorzystuje się wizerunki osób znanych i lubianych, którzy niekoniecznie muszą być ekspertami w danej dziedzinie, ale często bywają bardziej przekonywujący niż „nudni” fachowcy.

\footnotetext{
${ }^{47}$ Tamże.

${ }^{48}$ Http:www.sejm.gov.pl/oide.
} 
Posługiwanie się autorytetem ludzi popularnych było stosowane przede wszystkim przez „euroentuzjastów”. Prawdopodobnie wynika to z faktu, iż posiadali oni większe zasoby finansowe oraz, że więcej tzw. ludzi z pierwszych stron gazet podzielało ich poglądy. Jedną z takich osób była m.in. Pierwsza Dama Rzeczypospolitej, Jolanta Kwaśniewska, która w sondażu „Polityki” uzyskała pierwsze miejsce jako ewentualna kandydatka na prezydenta kraju, zdobywajacc 37\% poparcia ${ }^{49}$. To m.in. ona oraz wielu przedstawicieli świata kultury widniało na billboardach podpisanych niezbyt odkrywczym hasłem: „Tak, jestem Europejką” lub „Tak, jestem Europejczykiem”.

Warto również wspomnieć o takich programach telewizyjnych jak np.: „Europa da się lubić”, który teraz ma charakter wyłącznie rozrywkowy, jednak raczej nie tylko z powodów rozrywkowych byl emitowany przed referendum. Nie jest to bowiem program o Europie, a raczej o Unii Europejskiej, ponieważ jego gośćmi sa jedynie przedstawiciele krajów wchodzących w skład tejże organizacji. Trudno się tam bowiem doszukać, np.: Norwegów, Szwajcarów czy Ukraińców. Czołowa postacią tego programu jest popularny w Polsce, pochodzący z Niemiec, satyryk oraz aktor Steffen Möller. Oczywiście nie agitował on w programie, żeby głosować za UE, ale niewatpliwie samym swoim uczestnictwem tworzył on pozytywny wizerunek Unii.

Prounijne piosenki były śpiewane w przerwach podczas „Tygodnika politycznego Jedynki” przez Krzysztofa Krawczyka i Marylę Rodowicz ${ }^{50}$. Piosenkę o integracji europejskiej napisał również popularny zespół rockowy o charakterystycznej nazwie Róże Europy. Zagrali oni na $\mathrm{X}$ Spotkaniach Europejskich w Warszawie ${ }^{51}$. Inny znany muzyk rockowy Paweł Kukiz uczestniczył w prounijnych manifestacjach PO, mówiąc: „To, że cały splendor ma spłynąć w tej chwili na ekipę Millera i Jaskierni, Oleksego - tych samych ludzi, którzy kiedyś strzegli nienaruszalności sojuszy polsko-sowieckich, to dla mnie jest rzecz przerażająca. Ale to jest przede wszystkim dla nas" ${ }^{\text {} 52}$. Kampanie Platformy wspomagały również aktorki: Maja Komorowska i Ewa Błaszczyk oraz aktorzy: Daniel Olbrychski i Robert Gonera, który stwierdził: „Wejście Polski do Unii jest szansą jedzenia tortu w piętnastkę, a nie ciastka w pojedynkę" ${ }^{, 53}$. W kampanii Inicjatywy Obywatelskiej „Tak w Referendum” uczestniczył natomiast słynny skoczek narciarski Adam Małysz, któremu została

\footnotetext{
${ }^{49}$ J. Paradowska, M. Janicki, W. Władyka, Oblicza roku, „Polityka”, 2004, nr 1.

50 Tygodnik polityczny jedynki, TVP1, 05.06.2003.

51 J. Czekanowski, P. Klatt, Rock dla Unii, „Trybuna”, 12.05.2003.

${ }^{52}$ Cyt. za: Http:euro.pap.com.pl/cgi-bin/europap.pl.

53 Tamże.
} 
przyznana Nagroda Europejska. Tadeusz Mazowiecki powiedział zaś o nim, że: „Swoją postawą wprowadził Polskę do Europy”.54.

O ile uczciwe używanie autorytetów ekspertów nie może być nazwane manipulacja, to nie ma powodu, by nie nazwać manipulacja posługiwania się wizerunkiem ludzi popularnych. Jest to bowiem typowy argument emocjonalny pozbawiony jakiejkolwiek wartości merytorycznej, co nie znaczy oczywiście, że jest on nieskuteczny. Jest to również instrumentalne traktowanie zarówno przedmiotu debaty, jak i jej podmiotu, czyli społeczeństwa. Przypomina tu się wspomniany wyżej eksperyment $\mathrm{z}$ małpami, kiedy pod wpływem autorytetu małpy dominującej inne małpy zachowywały się tak samo. Czasami niektóre zachowania polityków sprawiaja wrażenie, jakby sprowadzali oni społeczeństwo do roli małp, a urnę wyborczą do klatki z bananami.

\section{Autorytet papieża i kościoła}

W dyskursie o integracji europejskiej, jak w każdej innej debacie politycznej w Polsce, nie mogło zabraknąć odwołań do autorytetu papieża. Politycy wszelkich opcji politycznych, zarówno odwołujących się do wartości chrześcijańskich, jak i laickich zdają sobie sprawę, jak ogromnym zaufaniem cieszy się Jan Paweł II. Sam papież również nie unika zaangażowania w sprawy polityczne. Problem polega jednak na tym, że nie wszystkie jego wypowiedzi są do końca jednoznaczne, co otwiera drogę do manipulacji. Wzorcowym przykładem jednocześnie instrumentalnego wykorzystywania autorytetu papieża i kościoła przez niektórych polityków lewicowych oraz manipulacji autorytetem papieża przez niektórych polityków uważających się za katolickich jest dyskurs unijny. Przy czym warto zaznaczyć, iż obie strony zarzucały sobie nawzajem manipulację. Niestety tylko jedna z nich mogła mieć rację.

Odwoływanie się do autorytetu papieża przez „euorentuzjastów” wynikało nie tylko z jego ogromnej popularności. Można powiedzieć, że zastosowali oni tutaj podobną strategię jak „eurosceptycy”, gdy odwoływali się do autorytetów urzędników unijnych lub prounijnych naukowców. Jak pisał Artur Schopenhauer: „Wygrywamy łatwo, mając po swojej stronie jakiś autorytet, który jest szanowany przez przeciwnika" ${ }^{95}$. Papież jest bardzo szanowany przez zdecydowana większość środowisk „eurosceptycznych”, a poza tym jako człowieka

\footnotetext{
54 Tamże.

55 A. Schopenhauer, Erystyka, czyli sæ̨tuka prowadzenia sporów, Warszawa 2002, s. 92.
} 
cieszącego się tak dużym autorytetem zdecydowana większość polityków nawet jeśli go nie szanuje, przynajmniej stara się robić takie wrażenie.

Po obu stronach, zarówno „eurosceptyków” jak i „euroentuzjastów”, angażowało się wielu przedstawicieli kościoła katolickiego. Jednym z księży „euroentuzjastycznych” był abp Henryk Muszyński, który przedstawił autorytet papieża w taki sposób, że niemożliwa jest żadna polemika: „Natomiast jestem przekonany, że to, co mówi Jan Paweł II pobudzi do refleksji, ponieważ papież ma bez wattpienia najpełniejsza wizję. $Z$ jednej strony, mimo nieobecności w Polsce, żyje polska rzeczywistością, a z drugiej strony ma wizję i perspektywę światową, wizję miejsca Polski nie tylko w Europie, ale w dobie globalizacji także w kontekście światowym. I myślę, że nikogo nie stać na bardziej obiektywny sąd niż właśnie papieża. $\mathrm{Na}$ osąd o wiele bardziej wolny, bezstronny aniżeli ludzi, którzy jak my w Polsce, przez dziesiątki lat byliśmy odizolowani" ${ }^{56}$. O ile przedstawiciel kościoła katolickiego, traktujacy papieża jako największy autorytet, nie musi wywoływać zdziwienia, to słowa padające $\mathrm{z}$ ust Aleksandra Kwaśniewskiego, człowieka nieustannie podkreślającego swój agnostycyzm, mogą budzić pewne watpliwości, co do ich szczerości: „Słowa, które wypowiedzial papież Jan Paweł II w sprawie obecności Polski w Europie, powinny być odpowiedzią na wszystkie wątpliwości”, ${ }^{57}$. Prezydent Polski stwierdził również: „Wierzę że słowa największego autorytetu, największego Polaka, trafią do osób wątpiących. Tych, których te słowa nie przekonały, mimo że powołują się na kościół, wiarę, no cóż można powiedzieć, musimy zostawić ich sumieniu i sądzę, że z wyrzutami sumienia"58. Swoje wystapienie w telewizji, w ostatni dzień kampanii referendalnej, prezydent również zaczął od cytowania słów papieża i stwierdził: „(...) tak mówił papież Polak do nas i wszystkich Europejczyków, 12 maja na Placu św. Piotra. Przypominam te słowa Ojca Świętego, wielkiego wizjonera, który tak bardzo wpłynął na przemianę oblicza naszej ojczystej ziemi’"59. Zdarzały się również wypowiedzi zwolenników UE, które nieco nadinterpretowały słowa papieskie, jak na przykład stwierdzenie przedstawiciela PiS-u, Kazimierza Michała Ujazdowskiego: „Wypowiedź Ojca Świętego to była manifestacja patriotyzmu ofensywnego, takiego wielkiego powiewu ducha jagiellońskiego" ${ }^{90}$. Na autorytet kościoła powoływała się również

${ }^{56}$ Cyt. za: http:euro.pap.com.pl/cgi-bin/europap.pl.

57 Tamże.

58 Tamże.

${ }^{59}$ Wystapienie Aleksandra Kwaśniewskiego, TVP1, 05.06.2003.

${ }^{60}$ Forum, TVP1, 06.05.2003. 
liberalna „Gazeta Wyborcza”: „Raduje, że Episkopat zajął tak mocne stanowisko: każdy katolik winien wziąć udział w referendum. A jak głosować? Podpowiadał Papież w czasie ostatniej pielgrzymki" ${ }^{\prime \prime}$. Cytowano również wypowiedź prymasa Glempa: „Bóg chce, byśmy weszli do wspólnej Europy. Taka jest wola Boża. Europa chce być z Polską, dlatego Polska powinna być z Europa - brzmi teraz wspólna deklaracja Episkopatu i Polskiej Rady Ekumenicznej",62. Warto zwrócić uwagę, że ksiądz prymas odwoływał się tutaj do autorytetu samego Boga, czego uczciwość w tym przypadku niestety bardzo trudno zweryfikować. Po jednoznacznych oświadczeniach Episkopatu oraz Jana Pawła II „euroentuzjaści” pisali z radością: „Od tej chwili żaden rycerz Radia Maryja i Ligi Polskich Rodzin nie może w dobrej wierze zaprzeczyć, że Kościół powiedział Europie $>$ tak $<"$ "63.

Początkowo wydawało się to bardzo prawdopodobne. Po przemówieniu papieża, wygłoszonym 19 maja 2003 roku do Polaków przybyłych w narodowej pielgrzymce do Rzymu, w którym padły słowa: „Wejście w struktury Unii Europejskiej, na równych prawach z innymi państwami, jest dla naszego narodu i bratnich narodów słowiańskich wyrazem jakiejś dziejowej sprawiedliwości, a z drugiej strony może stanowić ubogacenie Europy" ${ }^{\prime \prime}$, nawet o. Tadeusz Rydzyk stwierdził: „Jeżeli Ojciec Święty coś mówi, to my nie dyskutujemy z Ojcem Świętym i nie komentujemy jego wypowiedzi. My chcemy zgłębić jego naukę. Musimy zrozumieć, co on mówi. (...) Bardzo proszę słuchaczy Radia Maryja: jeśli telefonujecie, nie róbcie kampanii w tę czy tamtą stronę. (...) Pewien biskup powiedział o Unii Europejskiej: ta struktura nie jest niebem, kto tak mówi, kłamie. Nie jest też piekłem. Na pewno czyściec. Dla nas to może być wielki czyściec. (...) Być może mamy pewien czyściec przeżyć”, ${ }^{\circ}$. Z kolei Adam Szostkiewicz w „Polityce” napisał: „Według błyskawicznej sondy Pentora 70\% Polaków uznało wypowiedź Jana Pawła II za opowiedzenie się za Polską w Unii Europejskiej",66. Również reakcje polityków „eurosceptycznych” na słowa papieża były bardzo różne. Bogdan Pęk (LPR) stwierdził na przykład: „Ojciec Święty zapewne nie zna traktatu akcesyjnego i dokładnych warunków, na jakich chcą nas przyjąć do Unii Europejskiej. Pewnie prezydent Aleksander Kwaśniewski namówił papieża, by tak otwarcie poparł integrację Polski z

${ }^{61}$ J. Turnau, Biskupi na tak, „Gazeta Wyborcza”, 05.05.2003.

${ }^{62}$ Tamże.

63 Tamże.

${ }^{64}$ Cyt. za: Europa potrzebuje Polski, Polska potrzebuje Europy, „Angora”, 01.06.2003.

${ }^{65}$ Rozmowy niedokończone, Radio Maryja, 22.05.2003.

66 A. Szostkiewicz, Papież i kuglarze, „Polityka”, 2003, nr 22. 
Unia" ${ }^{97}$. Natomiast jego kolega partyjny, Marek Kotlinowski, powiedział: „Słowo papieskie nie jest jednoznaczne, w istocie przyznaje nam racje (docenia obawy eurosceptyków)" ${ }^{\$ 68}$.

Zanim doszło do jednoznacznego poparcia wejścia Polski do UE przez papieża, zarówno zwolennicy i przeciwnicy integracji wybierali dla siebie te cytaty, które były dla nich korzystne. Jednak niektórzy „eurosceptycy” nie przestali tego robić nawet, gdy Jan Paweł II ostatecznie dał do zrozumienia, że popiera rozszerzenie UE. Zygmunt Wrzodak, poseł LPR, jeszcze 5 czerwca mówił: „Chcemy takiej Europy, o jaką modli się Ojciec Święty. Chcemy być właścicielami, a nie najemnikami. Wierzę, że wygramy i będziemy żyli w niepodległej Polsce" ${ }^{\text {"69 }}$. Wykorzystał on więc fakt, iż papież sprzeciwia się UE w obecnym kształcie, ale zapomniał o tym, że według Jana Pawła II Polacy powinni wejść do UE po to, żeby ją zmienić. Taką samą metodę zastosował w „Tygodniku politycznym Jedynki” Jerzy Robert Nowak, mówiąc: „Przypomnę, że Ojciec Święty już szereg lat temu, mówił, że w Karcie Praw Europejskich zabrakło odniesienia do Boga" ${ }^{\text {"70 }}$. W tym samym programie dominikanin z Warszawy, brat Łukasz Miśko, powiedział w stronę „eurosceptyków”: „Bardzo przykro mi jest, że politycy chrześcijańscy tak łatwo rozprawili się z przesłaniem papieskim, mówiąc że za papieskim przesłaniem kryje się tylko ironia i pustka i że unia to tylko pieniądze, bo papież mówił zupełnie coś innego, mówił o wspólnocie wartości" "71. Co prawda wypowiedź ta była nieco erystyczna, ponieważ nikt z „eurosceptyków” nie powiedział, że za papieskim przesłaniem kryje się „ironia i pustka”. „Eurosceptycy” mówili tak natomiast o kampanii prounijnej w wykonaniu polityków, choć trzeba przyznać, że w pewnym sensie papież brał udział w agitacji na rzecz UE. Jednak „eurosceptycy” zastosowali jeszcze gorszą erystykę, ponieważ nie chcieli w ogóle dopuścić do głosu dominikanina. Podczas gdy mówił, starali się go przekrzyczeć hasłem: „równe prawa”72. Wielu „eurosceptyków” stwierdziło bowiem po wypowiedzi papieża, że poparłby on integrację Polski z UE, gdyby odbywała się ona na równych warunkach. Jednak albo nie do końca zwrócili uwage na to, co powiedział papież, albo świadomie manipulowali jego wypowiedzia. Mówił on bowiem o równych warunkach, ale z kontekstu wypowiedzi

${ }^{67}$ Cyt. za: Bez watpliwości, „Trybuna”, 20.05.2003.

${ }^{68}$ Cyt. za: A. Szostkiewicz, Papież i kuglarze, „Polityka”, 2003, nr 22.

${ }^{69}$ Cyt. za: http:euro.pap.com.pl/cgi-bin/europap.pl.

70 Tygodnik polityczny Jedynki, TVP1, 05.06.2003.

71 Tamże.

72 Tamże. 
wynika, iż według Jana Pawła II takie właśnie warunki udało się wynegocjować. Powiedział on bowiem, że: ,jest dla naszego narodu (...) wyrazem jakiejś dziejowej sprawiedliwości”73, a nie, że „byłoby”.

Specyfika dyskursu unijnego, wyróżniająca go spośród innych polskich debat publicznych, polega na tym, że tym razem Jan Paweł II stanął po stronie tych ugrupowań politycznych, które w większości przypadków kieruja się wartościami lewicowymi i liberalnymi. Choć stwierdzenie, że opowiedział się po stronie jakichś partii, jest z pewnością nadużyciem (raczej podzielał ich poglądy na temat integracji europejskiej), to nie ulga wattpliwości, że był przez te ugrupowania wykorzystany jako instrument marketingu politycznego. Nie można jednak wszystkim „euroentuzjastom” zarzucić instrumentalnego posługiwania się autorytetem papieża. Z pewnością wielu polityków prounijnej prawicy, odwołując się do słów papieża, robiła to szczerze, a i politykom lewicowym nie można zabraniać prawa do wiary chrześcijańskiej oraz szczerego kierowania się przesłaniem papieża, choć w tym przypadku jest to znacznie trudniejsze. W debacie unijnej manipulantami i tymi, którzy instrumentalnie posługiwali się autorytetem papieża, okazali się niektórzy „eurosceptycy”, którzy również bardzo często odbierali innym prawo do bycia katolikami. Byli też i tacy przeciwnicy UE, którzy stwierdzili, że maja inne zdanie niż Jan Paweł II, że być może nie zna on traktatu akcesyjnego. Prawdopodobnie ich zachowanie wynika z faktu, iż zostali przyparci do muru, trzeba jednak przyznać, że potrafili się nie zgodzić z najważniejszym dla siebie autorytetem, a to na pewno nie była łatwa decyzja i trudno powiedzieć, jak wielu ludzi potrafi zdobyć się na coś takiego. Pozostaje jeszcze jedno pytanie - o wartość merytoryczną autorytetu papieża w dyskursie unijnym? Czy uczciwe jest mieszanie autorytetów merytorycznych z autorytetami moralny i teologicznymi? Czy nie jest to po prostu podobny rodzaj manipulacji jak w przypadku posługiwania się osobami popularnymi? Nie ulega wattpliwości, że papież do takich właśnie osób należy. Należy wreszcie zapytać: czy można od jednego, starego już, schorowanego człowieka wymagać wiedzy z tak różnych dziedzin życia jak polityka, ekonomia, genetyka itp. Biorąc pod uwage, jak podzielone są zdania ekspertów na różne tematy, polska kultura polityczna wymaga od Jana Pawła II czegoś praktycznie niemożliwego.

\footnotetext{
${ }^{73}$ Cyt. za: Europa potrzebuje Polski, Polska potrzebuje Europy, „Angora”, 01.06.2003.
} 


\section{Podsumowanie}

Choć według wspomnianych wyżej sondaży, największa liczba Polaków nie ma żadnych autorytetów, w dyskursie unijnym nie brakowało powoływania się zarówno na przedstawicieli świata nauki, polityki, kultury, jak i kościoła. Oczywiście nie można mówić, że w każdym z tych przypadków odwoływanie się do autorytetu było manipulacją. Dotyczy to zwłaszcza autorytetów świata nauki, w przypadku, gdy byli oni cytowani w sposób uczciwy. Niestety, nigdy nie można mieć stuprocentowej pewności co do rzetelności w powoływaniu się na autorytet, a ponadto należy zauważyć, że wielu ekspertów ma bardzo odmienne zdania na podobne tematy. W takiej sytuacji przeciętni obywatele mają prawo czuć się zagubieni. W takim przypadku autorytety zamiast pomóc podjąć decyzję, dodatkowo ją utrudniaja. Nie oznacza to oczywiście, że należy przestać brać pod uwage poglądy ekspertów. Dobrze jest jednak zachować pewien dystans. Na pewno nie byłoby dobrym rozwiązaniem skupienie się wyłącznie na autorytetach emocjonalnych. One być może sprawiaja, że podjęcie decyzji wydaje się łatwiejsze, jednak na pewno nie jest to decyzja świadoma. Za autorytety emocjonalne można zaś uznać wszystkie inne oprócz naukowych, czyli: polityczne, kulturalne czy religijne. Chyba, że mamy do czynienia $z$ przypadkiem polityka, artysty czy księdza, którzy zajmują się profesjonalnie np.: integracją europejska. W przypadku artysty czy księdza jest to raczej mało prawdopodobne, w przypadku polityka całkiem możliwe, lecz trzeba wziąć pod uwagę, że opinia polityka zawsze będzie w jakiś sposób zaangażowana. Sztuka i religia to natomiast dziedziny, w których rozum odgrywa niewielką rolę, znacznie ważniejsze jest tu subiektywne poczucie estetyki lub - jak w przypadku religii wiara - pojęcie całkowicie transcendentne.

Oprócz uczciwości w powoływaniu się na autorytet ważny jest również sposób, w jaki się to robi. Inaczej jest bowiem w przypadku, gdy autorytet służy tylko do wzmocnienia argumentu, inaczej zaś, gdy jest on jedynym argumentem. Oczywiście nie można zarzucić ani „eurosceptykom”, ani „euroentuzjastom” stosowanie jedynie argumentum ad verecundiam (odwoływanie się do autorytetu) ${ }^{74}$, ponieważ wtedy praca ta musiałaby się składać tylko z jednego rozdziału. Warto jednak zwrócić uwagę na sposób, w jaki mówiono o poszczególnych autorytetach. Szczególnie charakterystyczny jest tu przypadek prezydenta Aleksandra Kwaśniewskiego, zdeklarowanego agnostyka, który przedstawiał Jana

${ }^{74}$ M. Korolko, dz. cyt., s. 103. 
Pawła II jako kogoś najwybitniejszego, z kim nie da się w żaden sposób polemizować. Jest to chwyt erystyczny polegający na zasłanianiu się autorytetem jako tarczą ${ }^{75}$. Nawet jeżeli Polacy uważaja papieża za największy autorytet moralny, trudno powiedzieć, czy uważaja go również za największy autorytet $\mathrm{w}$ dziedzinie integracji europejskiej. Jednak również w sprawach moralnych, choć Polacy uważaja papieża za największy autorytet, nie odnoszą się z takim samym entuzjazmem do jego nauk jak do niego samego.

Ciekawym przykładem zupełnie emocjonalnego i, można powiedzieć transcendentnego, posługiwania się autorytetem było uzurpowanie sobie przemawiania w imieniu Boga. Ten argument jest całkowicie nieweryfikowalny. Implikuje on jednocześnie, że ci, którzy się z nami nie zgadzaja, sprzeciwiaja się woli Boga. Do woli Bożej odwoływał się prymas Glemp. Natomiast inni, którzy go cytowali, jak „Gazeta Wyborcza” czy Zyta Gilowska (PO) ${ }^{76}$, można powiedzieć, że odwoływali się do autorytetu prymasa. Przekonanie o tym, że Bóg jest po jego stronie, nie opuszczało również posła LPR, Romana Giertycha: ,Jak już ludność Białegostoku wygwizdała pana prezydenta, pan prezydent nie przerwał swojej mowy to przyszła z pomocą opatrzność Boża i było gradobicie, oberwanie chmury i wtedy pan prezydent musiał salwować się ucieczką"

Niewatpliwie jednak najczęściej przywoływanym autorytetem był papież Jan Paweł II. Prawdopodobnie wynika to z faktu, iz byl jednym z nielicznych autorytetów, przywoływanych z równą gorliwością przez obie strony. Strona „eurosceptyczna” wykorzystywała go, ponieważ składa się w dużej mierze ze środowisk radykalno-katolickich, natomiast strona „euroentuzjastyczna”, wykorzystała sytuację, że po ich stronie znalazł się autorytet poważany przez przeciwnika. Ponadto obie strony zdawały sobie sprawę, iż papież jest właśnie tym autorytetem, który ma dla Polaków największe znaczenie. „Eurosceptycy” więc manipulowali słowami Jana Pawła II, natomiast „euroentuzjaści” za wszelką cenę starali się go pozyskać, jak i zresztą cały kościól. Nie bez powodu SLD zrezygnował z realizacji przed referendum swoich programowych hasel, jakimi była liberalizacja ustawy aborcyjnej oraz możliwość zawierania związków partnerskich przez homoseksualistów. Nie bez powodu prezydent i premier tak często spotykali się z papieżem. Trudno powiedzieć jak wyglądałaby sytuacja, gdyby to prezydentem był

${ }^{75}$ M. M. Czarnawska, Wspótczesny sofista, czyli nowe chwyty erystyczne, Warszawa 1995, s. 21.

${ }^{76}$ K. Kunicka, Z. Gilowska, Pan Bóg chce Polski w UE, „Tygodnik Nowy”, 2003, nr 21.

${ }^{77}$ Cyt. za: Ustyszane, „Angora”, 25.05.2003. 
np. Roman Giertych i ciagle namawiałby Jana Pawła II do opowiedzenia się przeciwko UE i by mu się to udało. Być może wtedy dyskusja byłaby trochę inna, trochę bardziej merytoryczna, ponieważ papież byłby autorytetem tylko dla jednej strony. Niestety, debata unijna w Polsce zamiast koncentrować się na korzyściach i stratach płynących z integracji europejskiej, w dużej mierze skoncentrowała się na interpretacji słów Karola Wojtyły. 